\title{
Kint3-4 protein from human plasminogen delays Ehrlich tumor growth in mice
}

\section{Efeito da proteína Kint3-4 do plasminogênio humano no crescimento do tumor de Ehrlich}

\author{
Cristina Maria de Souza'; Enio Ferreira²; Mônica Alves Neves Diniz Ferreira3; \\ Silvia Passos Andrade; ; Ivan Carlos Santos ${ }^{5}$; Jorge Luiz Pesquero ${ }^{6}$; Geovanni Dantas Cassali ${ }^{7}$
}

key words
Angiogenesis
Cell proliferation
Angiostatin
Neoplasm

\section{abstract}

Introduction and objective: Kint3-4 protein, originated from a genetic recombination of K1-3 and K1-4 human plasminogen segments, is recognized for its antiangiogenic and anti-inflammatory potential. This study aimed to evaluate the effect of Kint3-4 protein on tumor development in Swiss mice previously inoculated with Ehrlich tumor cells. Methods: The protein fragment was obtained from Pichia pastoris cloning and transformation. After tumor cell inoculation three different protocols were used to assess tumor growth: beginning (0-6 days), peak ( $0-12$ days) and after peak ( $0-18$ days). We analyzed tumor growth, histomorphological characteristics and immunohistochemistry by use of CDC47 (cellular proliferation marker) and CD31 (blood vessel marker). Results: Animals treated with Kint3-4 protein $(150 \mu \mathrm{g} / \mathrm{kg} / 48 \mathrm{~h})$ showed lower tumor growth in all protocols. Based on histological assessment, inflammation and tumor areas were also reduced. Moreover, both the lowest rate of tumor cell proliferation and low microvessel density were observed in animals treated with Kint3-4 protein compared with the untreated control group. Conclusion: The effect of Kint3-4 recombinant protein on tumor angiogenesis and control of malignant cell proliferation enhances the prospects of its use in clinical and antiangiogenic treatment.

\section{resumo}

Introdução e objetivo: A proteína Kint3-4 originou-se a partir de uma recombinação genética dos segmentos K1-3 e K1--4 do plasminogênio humano e é reconhecida por seu potencial anti-inflamatório e antiangiogênico. Este estudo teve como objetivo avaliar o efeito da proteína Kint3-4 no desenvolvimento de tumores em camundongos inoculados com células do tumor de Ehrlich. Métodos: O fragmento de proteína foi obtido por uma técnica de clonagem e transformação de Pichia pastoris. Três diferentes protocolos foram avaliados após a inoculação das células tumorais: no início (0-6 dias), no pico (0-12 dias) e após o pico (0-18 dias) de crescimento do tumor. Foram analisados o crescimento do tumor e as características histomorfológica e imuno-histoquímica com CDC47 (marcador de proliferação celular) e CD31 (marcador de vasos sanguíneos). Resultados: Os animais tratados com a proteína Kint3-4 (150 $\mathrm{kg} / \mathrm{kg} / 48 \mathrm{~h})$ nos três diferentes protocolos apresentaram menor crescimento do tumor. Áreas de inflamação e tumor também foram reduzidas, avaliadas por exame histológico. Além disso, a menor taxa de proliferação das células tumorais e a baixa densidade de microvasos foram observadas nos animais tratados com proteína Kint3-4 em comparação com o grupocontrole. Conclusão: A participação da proteína recombinante Kint3-4 na angiogênese tumoral e no controle da proliferação de células malignas abre perspectivas para seu uso no tratamento clínico como antiangiogênico.

\section{unitermos}

Angiogênese

Proliferação celular

Angiostatina

Neoplasia

1. Doutoranda e mestra em Patologia; professora adjunta da Fundação Comunitária de Ensino Superior de Itabira (FUNCESI).

2. Doutor em Patologia; professor adjunto da Universidade Federal de Lavras (UFLA).

3. Doutora em Fisiologia; professora adjunta da Universidade Federal de Minas Cerais (UFMC).

4. Doutora em Farmacologia; professora associada da UFMG.

5. Doutor em Fisiologia; professor adjunto da Universidade Federal de São João Del Rei (UFS)).

6. Doutor em Biologia Molecular; professor associado da UFMG.

7. Doutor em Patologia; professor associado da UFMG. 


\section{Introduction}

Tumor growth and metastasis are angiogenesis-dependent processes ${ }^{(4)}$. Tumor angiogenesis is induced by malignant cells and by the action of cytokines produced by leukocytes that are recruited during cancer development. This shows the association between tumor growth and inflammation ${ }^{(22)}$.

The advance in tumor therapy depends on identification of factors/molecules that influence and determine the growth of malignant cells. Among the endogenous angiogenic inhibitors, angiostatin has been shown to exert a range of antineoplasic actions (inhibition of angiogenesis in vivo and endothelial proliferation and migration in vitro). This molecule, first described by O'Reilly et al. ${ }^{(13)}$, is a kringle-containing fragment of plasminogen. Numerous studies have confirmed and extended the antiangiogenic/ antitumor effects of angiostatin in a variety of systems and tumors. In vivo and in vitro studies have shown antiproliferative, antiangiogenic and antitumor actions of angiostatin $^{(21)}$. Recently, it has been shown a direct effect of angiostatin on tumor cell themselves ${ }^{(5,6)}$. It has also been proposed that various mechanisms have been able to cleave plasminogen resulting in several angiostatin-related proteins with potent endothelial cell inhibitory activities and induction of apoptosis ${ }^{(19)}$. Indeed, studies with the recombinant protein referent to the three first kringles of angiostatin (K1-3) demonstrated the ability of the fragment to inhibit bovine endothelial cell proliferation in vitro, reduce tumor growth in vivo(18) and control neutrophils and macrophages migration inhibiting the inflammatory process $^{(1,12)}$. Other plasminogen derivatives encoding kringles 1-4 and kringles 1-5 have been shown to exert indirect antiangiogenic and direct antitumoral effects in experimental lung cancer supporting the notion that plasminogen derivatives exert a dual antitumor mechanism that affects both tumor angiogenesis and tumor cells ${ }^{(16)}$. In this study we used a recombinant protein, the Kint3-4, that presents 250 aminoacids, from the fragment K1-3 and 13 more aminoacids at $\mathrm{C}$-terminal end derived from angiostatin to test its efficacy as an antitumor agent.

\section{Material and methods}

\section{Cloning and transformation of Pichia pastoris}

The methodology used for this procedure has been described recently ${ }^{(14)}$. The fragment encoding amino acids 79 to 346 of human plasminogen was amplified from a cDNA library (Helica Biosystems, CA, USA ) using the primers GAATTCGTGTATCTCTCAGAGTGC and GCGGCCGCTTATGTGGGAGCCAATTG. The PCR product was cloned into PGEM-T (Promega) and subcloned into pPIC9 (Invitrogen, Corp, CA, USA) at EcoRI and Notl sites in accordance to manufacturer's recommendations. The pPIC9 containing the insert was linearized by using $\mathrm{Bg} / \mathrm{Il}$ and the product used to transform P. pastoris strain SMD1165. Kint3-4 expression was identified among transformed colonies by replica-plating them to methanol and selected those with reduced ability to grow on methanol. Two phenotypically distinct strains were developed, one was slow-growing on methanol (muts) and the other was still capable of utilizing methanol (mut ${ }^{+}$). These phenotypic differences were presumed to be due to the interruption of the AOX1 gene by insertion of the expression plasmid in the case of the muts phenotype.

\section{Fermentation and purification}

Positive clones selected were grown into a 1 liter shake flask containing $150 \mathrm{ml}$ YPD medium. The samples were incubated at $30^{\circ} \mathrm{C}, 240 \mathrm{rpm}$ for 14 hours in an incubator shaker (Marconi, SP, Brazil). At optical density 2-6 the entire volume of inoculum was transferred to a 14 I fermentor vessel (Bioflo 110, New Brunswick Scientific Co. Inc.) containing 5 liter of basal salts medium plus $4.4 \mathrm{ml} /$ /iter PTM1 trace metal solution and glycerol $(40 \mathrm{~g} / \text { liter })^{(17)}$. The temperature was controlled at $30^{\circ} \mathrm{C}$. Dissolved oxygen set-point was $30 \%$ and $\mathrm{pH}$ was set at 5 and automatically adjusted with $7 \%$ ammonium hydroxide solution. After 20 hours of fermentation the glycerol fed-batch process was initiated. The feeding medium consisted of $50 \%$ glycerol supplemented with $12 \mathrm{ml} /$ liter of trace metal solution. The feed rate was $24 \mathrm{ml} / \mathrm{liter} / \mathrm{h}^{(17)}$ until biomass reaches $200 \mathrm{~g} / \mathrm{l}$, when the induction phase was started. The induction medium consisted of $100 \%$ methanol supplemented with $12 \mathrm{ml} / \mathrm{l}$ of trace metal solution. The feeding was divided into three stages with different rates: first $24 \mathrm{~h}$ induction with $1 \mathrm{ml} / / / \mathrm{h} ; 24-48 \mathrm{~h}$, $2 \mathrm{ml} / \mathrm{l} / \mathrm{h}$ rate and $48-72 \mathrm{~h}, 3 \mathrm{ml} / \mathrm{l} / \mathrm{h}$. The recombinant protein was purified by a process involving tangential filtration at first step in a hollow-fiber system using a $5 \mathrm{kDa}$ cut-off membrane to separate low molecular mass contaminants. The protein from hollow fiber system was loaded in a gel filtration column (Sephadex G100, $2.5 \times 60 \mathrm{~cm}$ ) eluted with $0.1 \mathrm{M}$ sodium phosphate buffer $\mathrm{pH}$ 7. Partially purified recombinant Kint3-4 $(300 \mu \mathrm{g})$ was loaded on a Sephasil (C8) reverse-phase column (Pharmacia Biotech) eluted with a linear gradient from 0 to $100 \%$ acetonitrile containing $0.1 \%$ TFA. 


\section{Animals}

Sixty female Swiss mice (6-7 weeks, $30 \mathrm{~g}$ weight) were provided by the Central Animal Facility, Institute of Biological Sciences, Federal University of Minas Gerais (Belo Horizonte, Brazil). The animals were housed in groups of four provided with chow pellets and water ad libitum. The light-dark cycle was $12 \mathrm{~h}$ with lights on at 7:00 am and lights off at 7:00 p.m. Efforts were made to avoid all unnecessary distress to the animals. Housing, anesthesia and care adhered to the guidelines established by our local Institutional Animal Welfare Committee.

\section{Experimental tumor model and treatment}

The animals were inoculated in the plantar cushion of the left posterior hind limb with an injection $(50 \mu \mathrm{l})$ containing $2.5 \times 10^{6}$ of Ehrlich tumor cells taken from ascites from Swiss mice. The animals were divided into three groups of 10 animals each. Group 1 (0-6 days) was treated with three intraperitoneal doses of the protein Kint3-4 $(4.5 \mu \mathrm{g} / 300 \mu \mathrm{l} /$ animal) in intervals of 48 hours; group 2 (0-12 days) received six doses of the protein; and Group 3 (0-18 days) received the same amount of the protein on days 12,14 and 16 post tumor cell inoculation. The protocols were designed to determine the efficacy of the protein on proliferating tumor cells at distinct phases of growth. The animals in group 1 were killed six days after tumor cell inoculation, in group 2, 12 days post-inoculation and in group 3, 18 days after inoculation. Three different control groups received saline $(300 \mu \mathrm{l})$ and were killed following the same schedule.

During the whole experimental period tumor growth, body weight, water and food ingestion were determined.

Tumor growth was assessed with the use of a micrometer (Mitutoyo, measurement $0.01 \mathrm{~mm}$, series number 7301) performed before tumor cell inoculation and every day after that.

The animals of each group and their respective controls were killed $48 \mathrm{~h}$ after the last dose of the treatment or vehicle. Necropsies were performed and tumor, lymph nodes (popliteal and inguinal), spleen, liver, kidneys, lungs and heart were removed for histopathological analysis.

\section{Histopathological and immunohistochemical studies}

Tissues were fixed in formalin ( $10 \% \mathrm{w} / \mathrm{v}$ in phosphatebuffered saline - PBS pH 7.4) and sections $(4 \mu \mathrm{m})$ were stained with hematoxylin and eosin (HE) and processed for light-microscopic studies. All staining were performed in paraffin-embedded sections mounted in glass slides. To perform morphometric analysis, images of cross sections obtained from 20 fields per slide $\left(8,533 \mu \mathrm{m}^{2} /\right.$ field $)$ were obtained with a planapochromatic objective 40 in light microscopy (final magnification $=1,000 \times$ ). The images were digitized through a JVC TK-1270/JGB microcamera and transferred to an analyzer (Kontron Eletronics, Carl Zeiss - KS300 version 2).

In histological sections of tumor-bearing paw stained with $\mathrm{HE}$ the percentage of necrotic area, viable neoplastic tissue and inflammation were determined using a graticule of 25 dots. The images were captured with a microcamera Spot Insigh Color adapted to an Olympus Microscope (BX-40). Image analysis was performed using SPOT $^{\circledR}$ software version 3.4.5 and Corel DRAW ${ }^{\circledR}$ version 7.468 .

Tumor cell proliferative activity was evaluated by immunohistochemical study using the cell proliferation marker CDC47 - clone 47DC141 (Neomarkers). Histological sections $(4 \mu \mathrm{m})$ were stained by avidin-biotinylatedperoxidase complex (DAKO K0690). Negative control sections were run in parallel with noimmune mouse or rabbit serum. The incubation with the primary antibody (CDC47; 1:300) lasted for 60 min and peroxidase activity was revealed using diaminobenzidine (DAB-Dako). The index for this marker was obtained by estimating the percentage of positive cells in 500 tumor cells. The counting was performed in 15 fields with $40 x$ objective and $10 x$ ocular.

Immunohistochemical technique was also employed to determine the angiogenic index using anti-CD31 (Clone TLD-3A12 - Fitzgerald). The method described by Maeda et al. ${ }^{(10)}$, was used to count microvascular density (MVD) in hot spot areas (areas with higher number of blood vessels).

\section{Statistical analysis}

Experimental delineation was totally at random, with three treatments and 10 repetitions per treatment, one repetition per animal. Results are presented as mean \pm SEM. Comparisons between groups were carried out using Student's $t$-test for unpaired data. Quantification of metastasis was determined using Fisher's exact test. The statistical program used to analyze the data was GraphPad InStat version 3.0 statistic software. A $P$-value less than 0.05 was considered significant. 


\section{Results}

\section{Assessment of water and food ingestion and body weight}

The experimental groups were assessed separately in relation to their controls taking into account the three phases of tumor development: early growth (0-6 days post-tumor cell inoculation; group 1); development phase up to growth peak (0-12 days post-tumor cell inoculation; group 2) and post growth peak (12-18 days post-tumor cell inoculation; group 3). In group 1, it was observed decrease in food and water intake. In group 2, only water intake was less than in the control animals. The animals in the treated group1 were lighter compared with their controls. No difference regarding water and food intake or body weight was observed in group 3 .

\section{Assessment of tumor growth}

Figure 1 shows the effect of systemic administration of Kint3-4 protein on tumor growth on the three different phases of development. At days 4 and 6 post-tumor cell inoculation the tumor was smaller in the treated group 1 (Figure 1A). In group 2, the difference in tumor growth was detected from day 2 onwards (Figure 1B). In group 3 , the tumor size of about $5 \mathrm{~mm}$ in both groups that were allowed to grow without any treatment, continued to grow in the control animals but decreased in the treated group $48 \mathrm{~h}$ after the first injection until the end point day 18 posttumor cell inoculation (Figure 1C).

\section{Histological and morphometric analysis of the tumor}

The percentage of neoplastic and inflammation areas was less in tumors of treated animals compared with non treated animals in group 1. However, the necrosis increased in the treated animals in the same group. In tumors of treated animals in group 2 there were a decrease in the percentage of inflamed area and increase in tumor area. In tumors of treated animals in group 3, only neoplasia area was increased when compared with the control (Table ).

\section{Immunohistochemistry assessment}

The number of positive CDC47 tumor cells was decreased in all treated groups (1,2 and 3) relative to their controls (Figure 2A). The microvessel density as determined by counting the number of positive CD31 vessels was decreased in tumor of treated groups 2 and 3 (Figure 2B). It was observed less concentration of marked microvessels in the treated groups compared with non-treated animals. Representative immunohistochemistry sections of CDC47 and CD31 are shown in Figures 3 and $\mathbf{4}$.

\section{Metastases analyses}

In the three treated groups and controls there were no neoplastic cells in liver, spleen, kidneys, lungs or heart. Presence of malignant cells was observed in inguinal lymph node in group 2 and 3 in control and treated animals. In the popliteal lymph node metastasis was observed in the three groups (treated and control). In group 1 the animals presented lower number of metastases in this lymph node (control 50\%; treated 15\%; $p<0.05$ - Fisher's exact test).

\begin{tabular}{|c|c|c|c|c|c|c|}
\hline \multirow{3}{*}{$\begin{array}{r}\text { Table } \\
\text { Variables (\%) }\end{array}$} & \multicolumn{6}{|c|}{$\begin{array}{l}\text { Means and standard deviation of the morphometric variables of solid Ehrlich tumor features in } \\
\text { control and treated animals }\end{array}$} \\
\hline & \multicolumn{2}{|c|}{ Group 1 (0-6 days) } & \multicolumn{2}{|c|}{ Group 2 (0-12 days) } & \multicolumn{2}{|c|}{ Group 3 (0-18 days) } \\
\hline & Control & Treated & Control & Treated & Control & Treated \\
\hline Tumor area & $44.79 \pm 0.65$ & $42.820 .59 *$ & $40.66 \pm 0.59$ & $42.23 \pm 0.73^{*}$ & $44.93 \pm 0.57$ & $46.71 \pm 0.54$ \\
\hline Necrosis area & $28.82 \pm 0.31$ & $35.09 \pm 0.48^{*}$ & $29.56 \pm 0.71$ & $28.77 \pm 0.51$ & $34.43 \pm 0.93$ & $33.86 \pm 0.50$ \\
\hline $\begin{array}{l}\text { Inflammation } \\
\text { area }\end{array}$ & $11.70 \pm 0.67$ & $3.51 \pm 0.48^{*}$ & $8.52 \pm 0.36$ & $2.50 \pm 0.55^{*}$ & $6.05 \pm 0.50$ & $5.30 \pm 0.36$ \\
\hline $\begin{array}{l}\text { Hemorrhage } \\
\text { and edema } \\
\text { areas }\end{array}$ & $14.69 \pm 0.44$ & $18.58 \pm 0.53^{*}$ & $21.26 \pm 0.41$ & $26.50 \pm 0.61^{*}$ & $14.59 \pm 0.46$ & $14.13 \pm 0.49$ \\
\hline
\end{tabular}

${ }^{*} p<0,05$ - Values represent means $\pm S D$ of 10 animals in each group. 


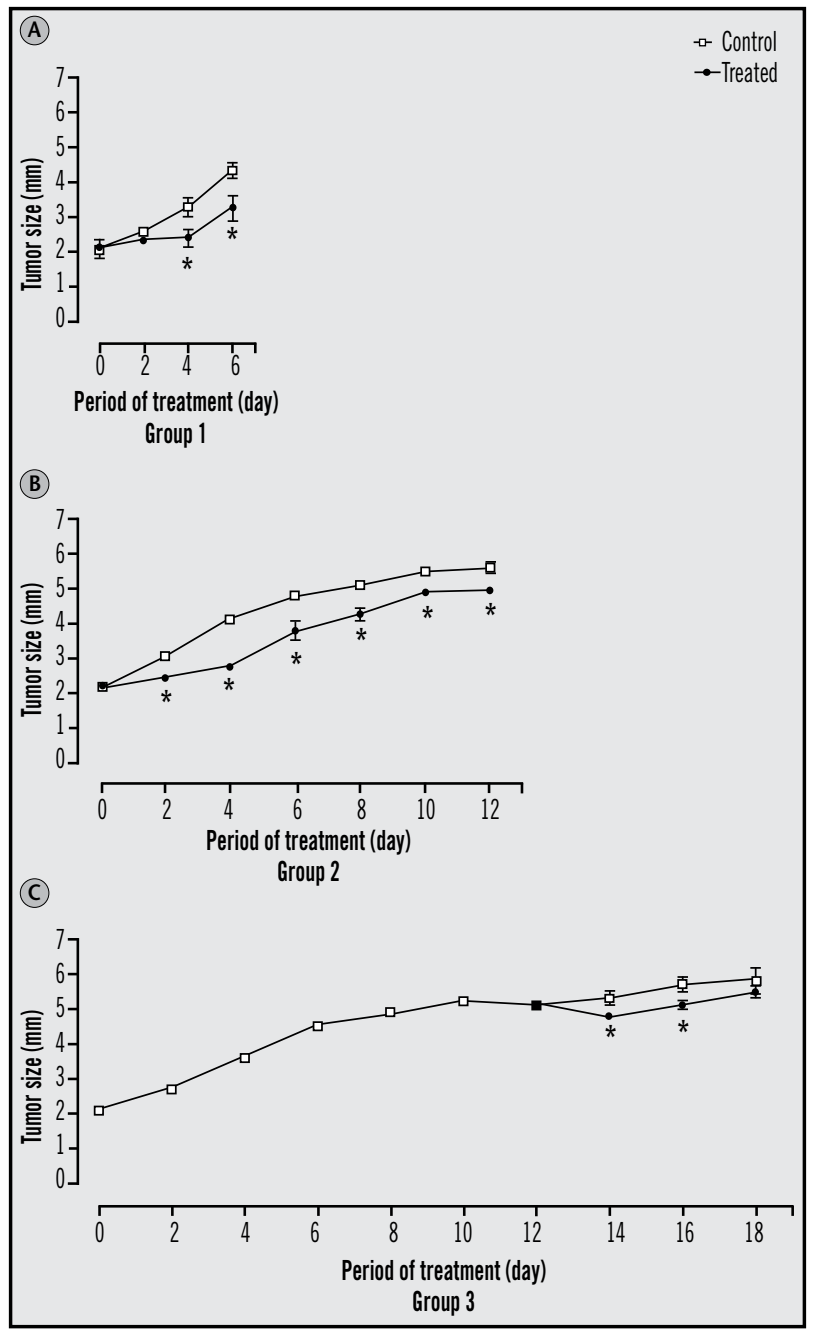

Figure 1 - Effect of systemic administration of Kint3-4 protein on Ehrlich tumor growth (A) Group 1 (0-6 days); (B) group 2 (0-12 days); (C) group 3 (0-18 days). Data represent mean $\pm S E M\left({ }^{*} p<0.05\right.$; $t$-test) significant difference between the values of control and treated groups.

\section{Discussion}

The control of the angiogenic process has been proposed as an important therapeutic strategy in pathological processes angiogenesis-dependent ${ }^{(20)}$. The discovery of new angiogenesis regulatory pathways has allowed the identification of various antiangiogenic compounds that are currently, being used in clinical trials. Among them, angiostatin, a plasminogen fragment has been tested in experimental tumors and shown to exert antitumor effects associated with inhibition of blood vessel formation ${ }^{(3,5,12,17,20)}$. Other plasminogen derivatives encoding different kringles, particularly kringles 1, 2 and 3 also exert important antiangiogenic and antiinflammatory activities ${ }^{(2,24)}$. Based on these findings, we proposed in this work that another plasminogen fragment (Kint3-4) would probably exhibit similar antitumor and antiangiogenic activities. By using a technique of cloning and transformation

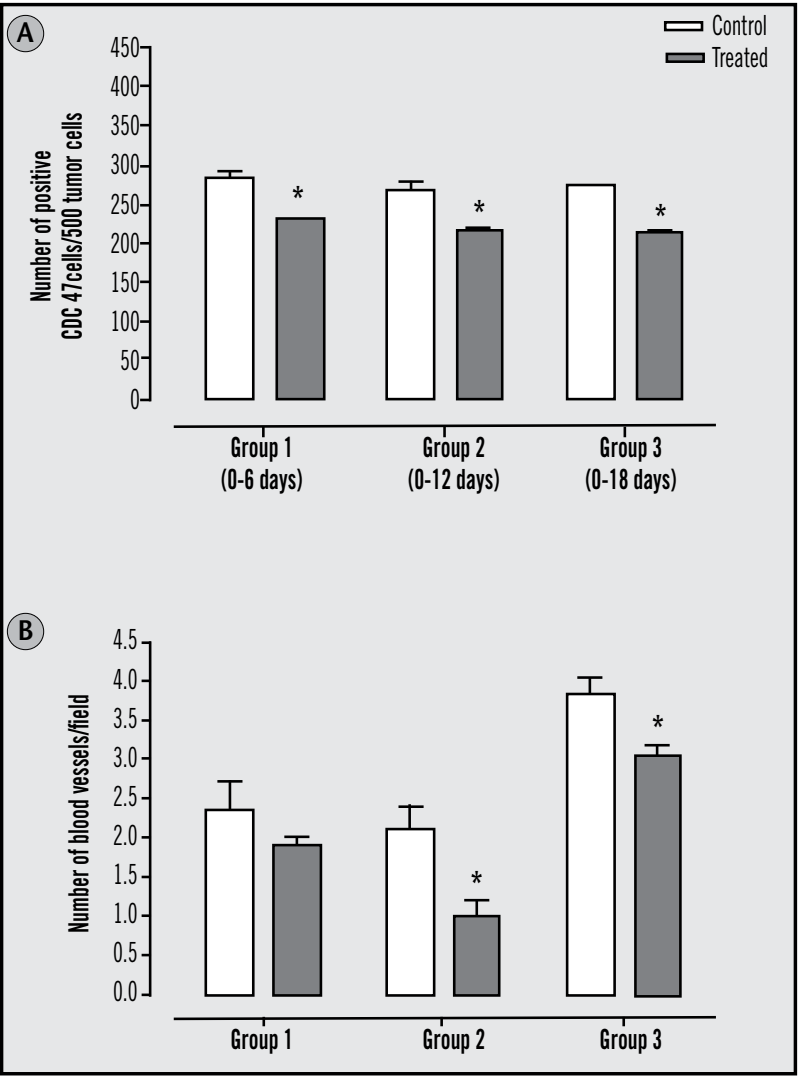

Figure 2 - Number of positive CDC47 tumor cells and number of blood vessels/field (A) Number of positive CDC47 tumor cells in 500 tumor cells. In all treated groups (1,2 and 3) the number of positive CDC47 tumor cells was decreased relative to their controls. (B) The number of positive CD31 vessels per field (vascular structures) was decreased in tumors of treated groups 2 and 3 compared with control animals. Data represent mean $\pm S E M\left({ }^{*} p<0.05\right.$; $t$-test) significant difference between the values of control and treated groups.

of Pichia pastoris to generate the kint3-4(14), we have shown that this protein was able to delay Ehrlich tumor growth, to decreased tumor microvessel density, to inhibit proliferation of neoplastic cells, attenuate inflammation areas and increased necrosis areas when administered systemically at different phases of tumor progression. Thus, our study not only confirms previous findings on the antitumor/antiangiogenic effect of plasminogen derivatives, but also provides new evidence that the kringles 3-4 share, at least in part, bioactivities presented by the other kringles $(1-4)^{(3,5)}$. It has been shown that kringles 2 and 3 are more efficient in inhibiting endothelial migration and proliferation than kringle 1 , and that the effect of segment 1-3 combined with kringle 4 on endothelial cells was similar to that of angiostatin ${ }^{(24)}$.

In the morphometric analysis of the tumors of treated animals, neoplasia, necrosis and inflammation areas were clearly decreased compared with that of tumors of untreated animals. It has been reported that angiostatin inhibited neutrophil recruitment and that these inflammatory cells express mRNA to ATP synthase ${ }^{(11)}$ and angiomotin ${ }^{(23)}$ that are 


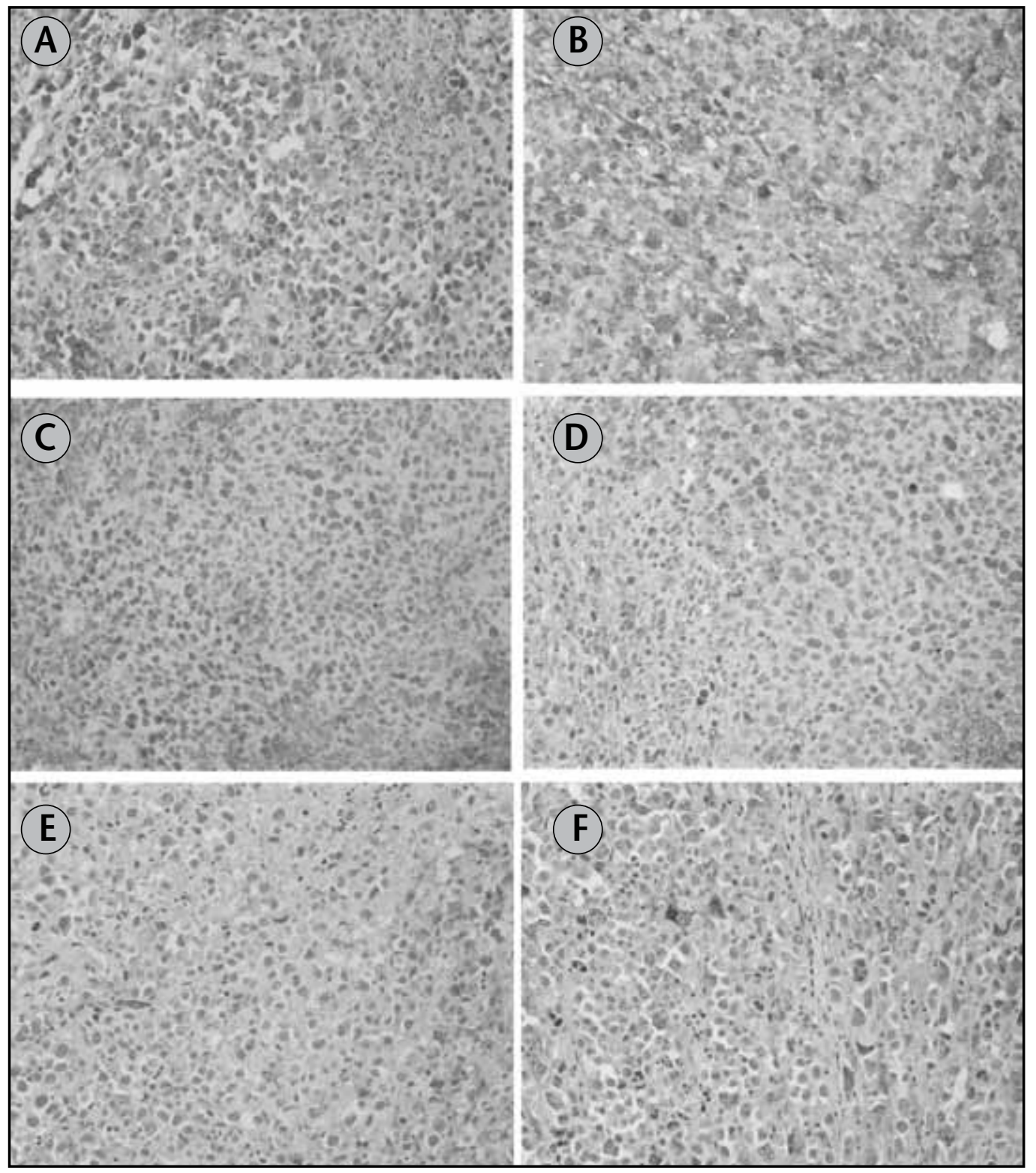

Figure 3 - Immunohistochemical reaction to CDC47/MCM-7 protein in Ehrlich tumor

Group 1: control (A) and treated (B) animals at day 6 post tumor cell inoculation; group 2: control (C) and treated (D) animals at day 12; group 3: control (E) and treated (F) animals at day 18. Nuclear immunolabeling, showing low number of positive cells in Kint3-4 treated animals of the three groups. 400x.

angiostatin receptors. Furthermore, upon stimulation human polymorphonuclear neutrophils release enzymatic activities that generate bioactive angiostatin fragments from purified plasminogen ${ }^{(14)}$. It is therefore pertinent to speculate that Kint3-4 can also mediate the antiinflammatory effect through these mechanisms in our experimental tumor. The expression of CDC47 in the tumor cells and CD31 in vascular structures were overall decreased by Kint3-4 treatment, indicating that both structures were targets for the protein. Our findings are in line with those reported by Kirsch et al.(7) and Sharma et al.(17) that demonstrated that angiostatin controls neoplastic proliferation indirectly by inducing the endothelial cells to become quiescent. Furthermore, Hayashi et al.(5) showed that the actions of kringles $\mathrm{K} 1-3$ and $\mathrm{K} 1-4$ are associated with inhibition of endothelial migration and proliferation.

The effects of the protein were more evident in the growth phase (days post tumor cell inoculation) probably due to the duration and/or total amount of the protein injected. Because Kint3-4 fragment was able to decrease the number of CD31 structures in tumor tissue and tumor development has been associated with new blood vessel formation ${ }^{(4)}$ it is likely that the antiangiogenic effect of the protein was able, at least in part, to delay Ehrlich tumor growth.

Although it has been demonstrated that the fragment K1-3 was able to prevent metastasis in other tumor model ${ }^{(9,18)}$, metastasis was observed in all our groups. 


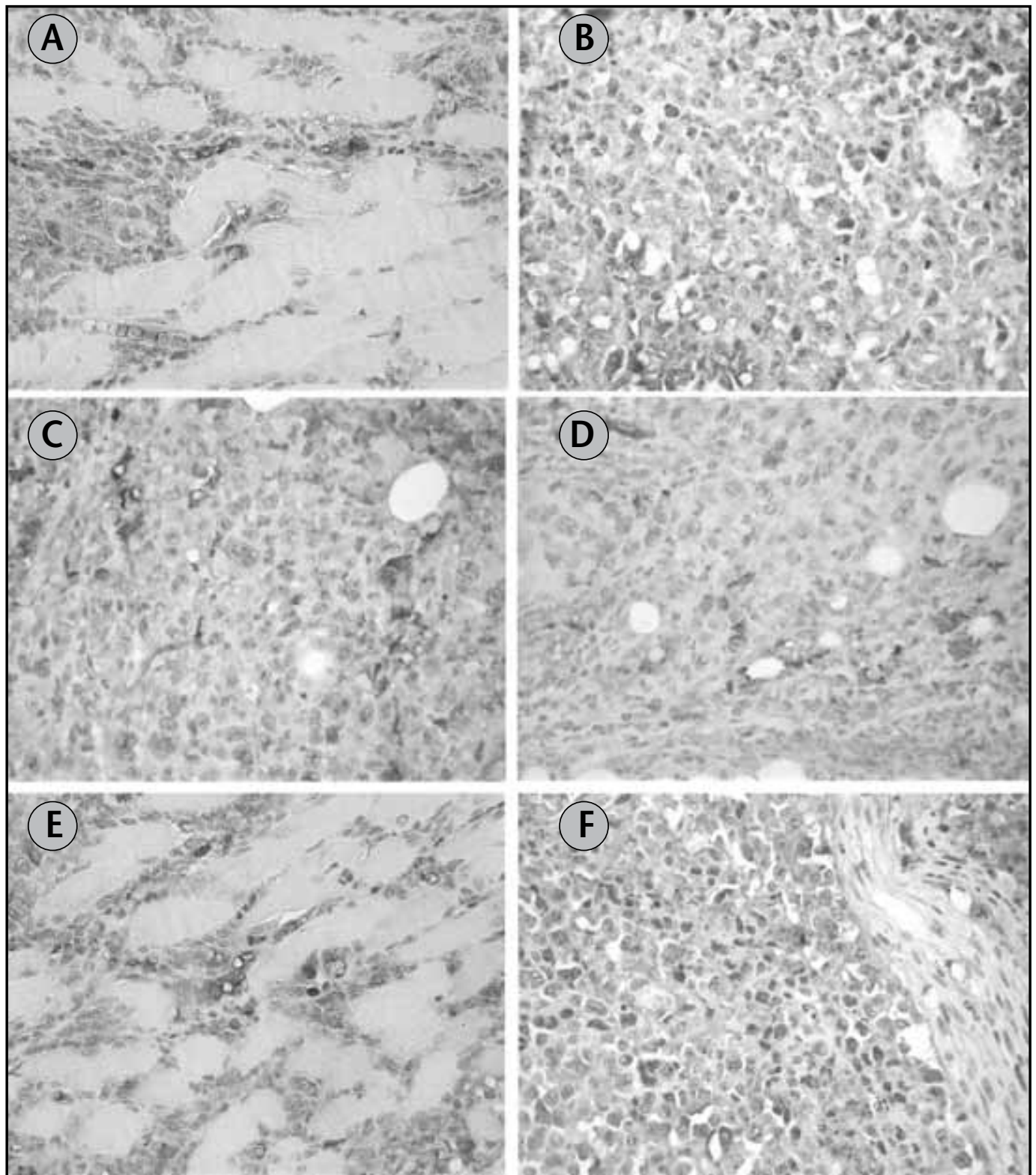

Figure 4 - Immunohistochemical reaction for CD31/TLD-3A12 protein in Ehrlich tumor

Group 1: control (A) and treated (B) animals at day 6 post tumor cell inoculation; group 2: control $(C)$ and treated $(D)$ animals at day 12; group 3: control (E) and treated (F) animals at day 18. Citoplasmatic immunolabeling, showing low number of positive cells in Kint3-4 treated animals of the three groups. 400x.

This lack of anti-metastatic effect may be attributed to the different experimental tumor (Lewis lung carcinoma, model of lung metastasis $)^{(9,18)}$, and/or plasminogen derivatives dosage used in the experiments.

Interestingly, the animals presented decrease in food and water intake and in body weight gain and this effect may be associated with the fact that plasminogen components modulate adipose tissue development ${ }^{(8)}$. However, this approach has not been dealt with in our experiments.

In conclusion, our findings provide additional evidence supporting the notion that antiangiogenic factors, such as the Kint3-4 protein, may be an alternative procedure for cancer therapy.

\section{Acknowledgements}

This work was supported in part by Fundação de Amparo a Pesquisa de Minas Gerais (FAPEMIG), Conselho Nacional de Desenvolvimento Científico e Tecnológico (CNPq) and Coordenação de Aperfeiçoamento de Pessoal de Nível Superior (CAPES). 


\section{Referências}

1. BENELLI, R. et al. Neutrophils as a key cellular target for angiostatin: implications for regulation of angiogenesis and inflammation. FASEB J, v. 16, p. 267-9, 2002.

2. $\mathrm{CAO}, \mathrm{Y}$. Endogenous angiogenesis inhibitors and their therapeutic implications. Int J Bioch Cell Bio, v. 33, p. 357-69, 2001.

3. CHEN, Y. H. et al. Anti-angiogenesis mediated by angiostatin K1-3, K1-4 and K1-4.5. Involvement of p53, FasL, AKT and mRNA deregulation. Thromb Haemost, v. 95, p. 668-77, 2006.

4. FOLKMAN, J. Role of angiogenesis in tumor growth and metastasis. Semin Oncol, v. 29, p. 15-8, 2002.

5. HAYASHI, M. et al. Plasminogen N-terminal activation peptide modulates the activity of angiostatin-related peptides on endothelial cell proliferation and migration. Biochem Biophys Res Commun, v. 1, p. 1-6, 2008.

6. JI, W. R. et al. A selective inhibition by kringle 5 of human plasminogen on endothelial cell migration, an important process in angiogenesis. Biochem Biophys Res Commun, v. 247, p. 414-9, 1998a.

7. KIRSCH, M.; SCHACKERT, G.; BLACK, P. M. Metastasis and angiogenesis. Cancer Treat Res, v. 117, p. 285-304, 2004.

8. LIJNEN, H. R.; FREDERIX, L.; SCROYEN, I. Deficiency of plasminogen activator inhibitor-2 impairs nutritionally induced murine adipose tissue development. J Thromb Haemost, v. 5, p. 2259-65, 2007.

9. MACDONALD, N. J. et al. The tumor-suppressing activity of angiostatin protein resides within kringles 1 to 3 . Bioch Bioph Res Com, v. 264, p. 469-77, 1999.

10. MAEDA, K. et al. Tumour angiogenesis and tumour cell proliferation as prognostic indicators in gastric carcinoma. Br J Cancer, v. 72, p. 319-23, 1995.

11. MOSER, T. L. et al. Angiostatin binds ATP synthase on the surface of human endothelial cells. Proc Natl Acad Sci, v. 96 , p. 2811-6, 2001.

12. MOULTON, K. S. etal. Inhibition of plaque neovasculariztion reduces machrophage accumulation and progression of advanced atherosclerosis. Proc Natl Acad Sci, v. 100, p. 4736-41, 2003.
13. O'REILLY, M. S. et al. Angiostatin: a novel angiogenesis inhibitor that mediates the suppression of metastases by a Lewis lung carcinoma. Cell, v. 79, p. 315-28, 1994.

14. SANTOS, I. C. et al. Angiostatic activity of human plasminogen fragments is highly dependent on glycosylation. Cancer Sci, v. 101, p. 453-9, 2010.

15. SCAPINI, P. et al. Generation of biologically active angiostatin kringle 1-3 by activated human neutrophils. J Immunol, v. 168, p. 5798-804, 2002.

16. SCHMITZ, V. et al. Plasminogen derivatives encoding kringles 1-4 and kringles 1-5 exert indirect antiangiogenic and direct antitumoral effects in experimental lung cancer. Cancer Invest, v. 26, p. 464-70, 2008.

17. SHARMA, M. R.; TUSZYNSKI, G. P.; SHARMA M. C. Angiostatin-induced inhibition of endothelial cell proliferation/apoptosis is associated with the downregulation of cell cycle regulatory protein cdk5. J Cell Biochem, v. 2, p. 398-409, 2004.

18. SIM, B. K. L. et al. A recombinant human angiostatin protein inhibits experimental primary and metastatic cancer. Cancer Res, v. 57, p. 1329-34, 1997.

19. SOFF, G. A. Angiostatin and angiostatin-related proteins. Cancer Metastasis Rev, v. 19, p. 97-107, 2000.

20. STATON, C. A.; REED, M. W.; BROWN, N. J. A critical analysis of current in vitro and in vivo angiogenesis assays. Int J Exp Pathol, v. 90, p. 195-221, 2009.

21. TABRUYN, S. P.; GRIFFIOEN, A. W. Molecular pathways of angiogenesis inhibition. Biochem Biophys Res Commun, v. 355, p. 1-5, 2007.

22. TAZZYMAN, S.; LEWIS, C. E.; MURDOCH, C. Neutrophils: key mediators of tumour angiogenesis. Int J Exp Pathol, v. 90, p. 222-31, 2009.

23. TROYANOVSKY, B. et al. Angiomotin: an angiostatin binding protein that regulates endothelial cell migration and tube formation. J Cell Biol, v. 152, p. 1247-54, 2001.

24. WEIDONG-RICHARD, J. I. et al. Characterization of kringle domains of angiostatina as antagonists of endothelial cell migration, an important process in angiogenesis. FASEB J, v. 12, p. 1731-8, 1998b

\begin{tabular}{l|l} 
& Endereço para correspondência \\
\hline Ceovanni Dantas Cassali \\
Departamento de Patologia Ceral - Instituto \\
de Ciências Biológicas \\
Universidade Federal de Minas Cerais \\
Av. Antônio Carlos, 6.627 - Campus Pampulha \\
CEP: $31270-901$ - Belo Horizonte-MC \\
Caixa postal: 486 \\
Fax: (31) 3409-2879
\end{tabular}

